\title{
Head teachers and students opinions about classroom factors that affect performance of students in integrated science at the Junior High Schools in Kumasi Metropolis
}

\author{
Michael Owusu, Charles Agyei Amoah, Laud Teye Nartey, Richard Akwasi Frimpong, \\ Science Department, Wesley College of Education, Kumasi-Ghana \\ Science Department, OLA College of Education, Cape Coast-Ghana \\ Science Department, OLA College of Education, Cape Coast-Ghana \\ Science Department, Agogo Presbyterian College of Education, Agogo-Ghana
}

\begin{abstract}
The purpose of the study is to find out the opinions of head teachers and students on classroom factors that affect performance of students in integrated science at the Junior High Schools in Kumasi Metropolis. The study used a descriptive survey. The sampling procedure employed for the study was both random and purposive sampling. A sample of two hundred and twenty (220) subjects participated in the study. The instruments that were used in the study were questionnaire and interview schedule. It was found out that most of the students in the public schools have greater access to integrated science text books as against their private school counterparts. Supervision is regularly carried out in the private schools by the head teachers but not much can be seen at the public schools and this has the tendency of improving teaching and learning of science at the private school. It was recommended that effective supervision must be performed regularly by heads of schools during integrated science lessons.
\end{abstract}

Keywords: Classroom factors, Instructional approach, Critical thinking.

\section{Introduction}

There are so many classroom factors that affect performance of students in integrated science at the Junior High Schools in Ghana. These factors are so important that care must be taken in order to control them. Some of these factors include teacher-student relationship, supervisory role, resource materials, instructional methods, class size and physical infrastructure. There are numerous teaching strategies or instructional methods that the science teacher can use in teaching the subject. Modern science teaching strategies involve the deliberate planning and organization of teaching-learning experiences and situations in the light of psychological and pedagogical principles with the view of achieving specific goals (Balogun et al, 1984).

To begin with, theoretical approach as a teaching strategy is a process of delivering verbally a body of knowledge according to pre-planned scheme (Brown, Oke \& Brown, 1982). This method according to Brown et al, (1982) is also known as the lecture method. Thus the emphasis is on writing notes on discoveries made by scientists. By this method, the teacher prepares and gives out information verbally to students without students' participation in the lesson. The students therefore listen, take down notes and memorize facts and concepts. This approach to science teaching makes students get bored during science lessons. Also see scientific concepts as abstract and difficult (Reisman \& Payne, 1987). This method according to Reisman and Payne (1987) is against the principle of learning by doing. Lecture method reduces teacher- students' interaction. However, this method of teaching is economical because no laboratory and expensive apparatus are required. It also encourages efficiency in time management since a single teacher can teach any number of students at a time (Brown et al, 1982). 
According to Wadsworth (1989) people followed the theoretical approach due to limited knowledge of science that the students possessed. In modern times Wadsworth (1989) stated that science is seen more to be practically oriented or activity based. Students enjoy science lessons when they are involved in activities concerning the topic. There is therefore the need to adopt the activity-based and inquiry methods in the teaching of science especially at the basic and secondary levels (Reisman \& Payne, 1987).

Secondly, discussion as a teaching strategy is one of the best ways of helping students to understand and learn ideas (Hake, 1993). According to Hake (1993), when students are given the chance to talk about things, it becomes easier to find out their knowledge in that topic. In order that learners see clearly how an idea applies to everyday life, they must be given the opportunity to use the discussion approach, and that the teacher only acts as a catalyst during the interaction among the students (Akpan, 1992). According to Graves (1985), in situations where class discussions are frequent, each student develops self confidence since he realizes that he is contributing something. This method provides an excellent opportunity for students to practice their oral communication skills. It also encourages critical and evaluative thinking (Graves, 1985).

Another teaching strategy is an activity-based method. It is the process of assisting students to discover their own knowledge through an activity (Mensah, 1992). According to Mensah (1992), in addition to acquisition of knowledge, the approach also leads to acquisition of process skills such as measuring, recording, analyzing and interpretation of data. Activity-based method is more of a child-entered approach, as such, students may learn better and faster when they are taught through activities (Reisman \& Payne, 1987). When a student performs an activity as an individual, the learner easily understands and never forgets (Mensah, 1992).

According to Mensah (1992), the activity method is used to teach science in which the student is at the centre of the learning process and made to interact with materials and experience things for him or herself.

With regards to resource materials, Walklin (1982) stated that science is a discipline, which is difficult to be understood or studied when its teaching is devoid of any practical activity. According to Walklin (1982), materials and equipment play a very important role in the teaching and learning of science and must therefore be adequately provided at all levels of education.

The science teacher needs enough teaching and learning materials in order to help learners develop scientific skills, knowledge and attitude toward science (UNESCO, 2004). However, the successful use of science materials depends very much on the resourcefulness of the teacher (Driver, Guesne \& Tiberghien, 1985). Driver et al, (1985) stated that children naturally attempt to make sense of the world in which they live through their previous experiences, their current knowledge and the use of language. This conception according to Perrot (1982) influences the way they observe events, the interpretation they offer for observation and the strategies they use to acquire new information including text and experimenting.

Zimmerman (1998) observed that class size is determined by variables such as the subject, the age and the psychological maturation of the learners. NRC (1999) in an examination on class size led to the conclusion that more meaningful research on this variables must take into account the methods used in teaching classes of different sizes.

A study by Corman (2001) illuminates the complexities of large class sizes. Corman adds that science teachers can use small group approach to address some of the problems posed by large class sizes.

A more general definition of supervision is given by Gordon (2005). He provides a well argued definition on current practical supervision. He defines supervision as overseeing an activity or group of activities. In a review of research on supervision, Kimball and Lovell (1983) perceived supervision to consist of all the activities leading to instruction, activities related to morale, improving human relationship, in-service education, and curriculum development.

According to Pollard (1994), modern supervision in education for example, is considered any service for teachers that eventually results in improving instruction, learning and curriculum. Neagly and Evans 
(1980), explain supervision as dynamic, democratic actions designed to improve instructions through the continued growth of all concerned individuals such as the child, the teacher, the supervisor, the administrator and the parent or other lay person.

\section{Statement of the Problem}

Science is regarded by many people as a discipline based on practical and analytical activity. Instructional approaches in science are therefore expected to be premised on hands-on and minds-on tasks (EIRMA, 2009). Such approaches are envisaged as enhancing the development of critical and analytical thinking skills, including science inquiry, problem solving and decision-making ability. However, while most of the science education community consent to the use of pedagogical practices based on inquiry-based methods, the reality of classroom practices is that science teaching is rarely inquiry based, especially at high school level (Allen, 2008). Similarly, other higher order thinking skills such as decision-making and critical thinking are seldom developed.

Most science educators, particularly in developing countries, present science as a theoretical body of knowledge characterized by facts, concepts and theories, with minimal or no practical work (Barmby, Kind \& Jones, 2008; Onwu \& Stoffels, 2005). In cases where practical experiments are conducted, learners usually follow stringent instructions from the educator or a practical manual in order to carry out an experiment to confirm results that are already known (Kang \& Wallace, 2005).

The problem of lack of practical and analytical activity in science classrooms is more profound in rural areas, where there are large under-resourced classes. For instance, in Ghana rural schools, practical experiments are often performed as demonstrations by educators, partly owing to large classes and insufficient resources (Onwu \& Stoffels, 2005). This greatly affects the performance of the students in science. This has necessitated the need to find out the opinions of head teachers and students about classroom factors that affect performance of students in integrated science at the Junior High Schools in Kumasi Metropolis in Ghana.

\section{Purpose of the Study}

The purpose of the study is to find out the opinions of head teachers and students on classroom factors that affect performance of students in integrated science at the Junior High Schools in Kumasi Metropolis

\section{Research Questions}

1. What are the opinions of public and private junior high school students in relation to classroom factors on performance of students in integrated science?

2. What are the opinions of heads of public and private junior high schools about classroom supervision and its effect on performance of students in integrated science?

\section{Methodology}

The study used a descriptive survey. The target population for the study was integrated science teachers, students and head teachers from J.H.S in some selected schools in the Kumasi Metropolis in the Ashanti region of Ghana. The sampling procedure employed for the study was both random and purposive sampling. While the head teachers were purposively sampled, the students were randomly selected.

Ten (10) private schools out of twenty-five (25) and ten (10) public schools out of thirty-two (32) were selected making a total of twenty (20) schools. Five (10) each were randomly selected from each of the public schools and five (10) each from each of the private schools resulting in a total of two hundred (200) participating in the study. The head teacher of each of the twenty (20) schools was also chosen, making a total of twenty (20) head teachers taking part in the study. All together, a sample of two hundred and twenty (220) subjects participated in the study.

The instruments that were used in the study were questionnaire and interview schedule. The questionnaire was developed based on the research questions and through information derived from the related literature. All the questionnaire items were developed in consultation with my supervisors and experts providing excellent advice for correction and amendment to ensure that the instrument was valid. 
The test-retest method was used to test for the reliability of the instruments. A pilot test of the study was personally conducted. Students, head teachers and science teachers of six selected basic schools in the Kumasi metropolis which included three private and three public junior high schools were used for the pilot study. The items were administered to the respondents and re-administered after three weeks so as to minimise errors and improve upon the reliability and content validity. Percentages of the responses of the items of the questionnaires were found.

The pilot test was used to enhance content reliability and validity of the instrument. It also improved the quality of the questions since those with ambiguities were corrected before the actual instrument was administered. The comments given by respondents on the items enabled the Researcher to remove all the questions which looked ambiguous. The clarity of the questions was therefore ensured.

The Cronbach Coefficient Alpha was determined as a means of measuring the internal consistency of the items of each of the questionnaire. The Cronbach Coefficient Alpha for the science teachers' questionnaire determined was 0.72 , students' questionnaire was 0.75 and the head teachers' questionnaire was 0.74 .

\section{Results/Discussion \\ Research Question 1}

What are the opinions of public and private junior high school students in relation to classroom factors?

\section{The factors considered included;}

- Participation of the students in science lessons,

- Understanding in science lessons,

- Access to text books,

- Accessibility of science resource materials to the learners.

Students' responses on classroom factors that affect performance are presented in table 1.

Table 1: Students' responses to classroom factors that affect performance

\begin{tabular}{|lcc|}
\hline & Public & Private \\
\hline Item & Yes & Yes \\
\hline $\begin{array}{l}\text { Participation in } \\
\text { science lessons }\end{array}$ & $45(45 \%)$ & $65(65 \%)$ \\
\hline $\begin{array}{l}\text { Understanding } \\
\text { science lessons }\end{array}$ & $30(30 \%)$ & $75(75 \%)$ \\
\hline $\begin{array}{l}\text { Supply of science } \\
\text { text books by school }\end{array}$ & $50(50 \%)$ & $40(40 \%)$ \\
\hline Performing laboratory work & $10(10 \%)$ & $85(85 \%)$ \\
\hline
\end{tabular}

From Table 1, out of the one hundred public school students who answered the questionnaire, fortyfive percent $(45 \%)$ of them said that they actively participate in science lessons as against sixty-five percent $(65 \%)$ of their counterparts from the private schools. The differences in the percentages of those who participate may account for the kind of methods employed during the teaching of integrated science by their science teachers. This is because public school science teachers used method of teaching that was mainly teacher-centered whereas those in the private schools mostly used method that was child-centered approach in their teaching (Owusu, 2011). Hence, most of the students in the private schools are likely to participate more in their lessons than their counterparts from the public schools. However, Reisman and Payne (1987) have noted that activity-based method is more of child-centered approach and that students may learn better 
and faster when they are taught through activities conducted by them. This method according to Reisman and Payne (1987) takes full advantage of the students' individual differences and abilities.

From Table 1, it shows that only thirty percent (30\%) of the public school students in the study area indicated that they understand what they are taught in science as against seventy-five percent (75\%) of their private school counterparts who also understand their science teachers when they are taught integrated science. It is easy to conclude that the kind of method private school science teachers employ, which is main activity oriented perhaps improved understanding in that school type. This is because according to Mensah (1992), when a student performs an activity as an individual, he/she easily understands and never forgets.

On the issue of science text books that are supplied to students, fifty percent (50\%) of the public school students said that they are supplied with science text books by the schools whereas only forty percent $(40 \%)$ of their private school students have access to science text books from their respective schools. Studies by Smith (1990) indicate that the use of science text books by students helps them to read ahead, have ideas about the topics, and know activities of coverage, depth and sequence. Smith (1990) further indicated in the same study that when students have access to science text books, they learn scientific explanations to phenomena on their own.

Table 1 show that only ten percent $(10 \%)$ of the public school students in the study area indicated that they performed laboratory work as against eighty-five percent $(85 \%)$ of their private school counterparts who also embarked on laboratory work. However, studies by Jenkins (1998) have shown that involving students in laboratory work is seen to provide scientific literacy as well as preparing students for further study, work and citizenship.

The following are the major findings of research question one:

- Majority of the private school students participate a lot during integrated science lessons as against their public school counterparts.

- Most of the students in the private schools perform laboratory work as against their counterparts in the public schools.

- Most of the students in the public schools have greater access to integrated science text books as against their private school counterparts.

\section{Research Question 2}

What are the opinions of heads of public and private junior high schools on classroom supervision?

The opinions expressed by twenty (20) head teachers on classroom supervision are converted into percentages as shown in Table 2.

Table 2: Opinions of heads of schools on classroom supervision

\begin{tabular}{|lcc|}
\hline & Public & Private \\
\hline Item & Yes & Yes \\
\hline $\begin{array}{l}\text { Supervision as a } \\
\text { key to successful } \\
\text { educational } \\
\text { programme }\end{array}$ & $10(100 \%)$ & $10(100 \%)$ \\
\hline $\begin{array}{l}\text { Regular } \\
\text { supervision in } \\
\text { science lessons }\end{array}$ & $6(60 \%)$ & $10(100 \%)$ \\
\hline
\end{tabular}


Regular

supervision in

other subjects

$7(70 \%)$

$10(100 \%)$

Discussion with

teachers after

supervision

$2(20 \%)$

$10(100 \%)$

Table 2 shows the opinions of both private and public school head teachers who took part in this study in classroom supervision including teaching and learning of integrated science. All the ten (10) head teachers each from both private and public J.H.S who answered the questionnaire agreed that supervision is seen as a key to successful educational programme. Pollard (1994) sees supervision in education as a service for teachers that eventually results in improving instruction, learning and curriculum. Also, Neagly and Evans (1980) consider supervision as an action designed to improve instructions.

On the question of whether supervision is regularly carried out in the schools during integrated science teaching, out of the ten (10) public school head teachers who responded to the questionnaire, six (6) representing sixty percent (60\%) agreed to be performing the task. On the other hand, all the ten (10) private school head teachers, representing one hundred percent $(100 \%)$ supervise their science teachers during integrated science lessons regularly. The responses were not different concerning supervision in other subject areas in the private schools.

On the issue of discussion of the outcome of the supervision with teachers concern, only two (2) representing twenty percent $(20 \%)$ of the public school head teachers agreed to be doing so. On the other hand, all the private school head teachers, representing one hundred percent (100\%) agreed to be doing that.

Considering all the classroom factors that were sourced in this study, it appears the private schools in the study areas are better positioned to render quality education to their students than their public school counterparts. Apart from resource materials and equipment that most of the public schools are endowed with, the private schools have better internal mechanisms that are likely to improve on performance.

From the research question two, the major findings are as follow:

- Supervision is regularly carried out in the private schools but not seen at the public schools.

- The outcome of supervision is discussed with the teachers concern in the private schools but it is not regularly done at the public schools.

\section{Interview items and responses from the students}

I: Do you involve yourself in science lessons conducted during teaching and learning of integrated science? State the reason(s) for your answer.

A1: We don't actually involve ourselves during science lessons. This is because our science teacher only dictates the notes for us to write. Therefore there is nothing more left for the students to do or participate in. A2: Well, we sometimes do participate but most often, our teacher dictates notes for us during integrated science lessons.

B1: We always get involve in science lessons. This is because our science teacher always gives us materials to work with whenever we have science lessons. We also do a lot of discussions. We always work in small groups, and therefore everybody does get involved.

B2: We are always happy whenever we have integrated science because our teacher mostly makes us perform practical work in small groups. Our science teacher discusses o lot with us, especially where everybody seems to have different opinions. Therefore everybody gets involved.

When students from public school were asked whether they take part in science lessons, all of them said that they do not take part. The students continued by saying that their science teachers dictate notes for them. The private school students on the other hand said that they participate fully in science lessons because their 
science teachers allow them to work in small groups. The private school students said that their science teachers discuss a lot with them during integrated science lessons and makes them perform activities. Studies by Hake (1993) have revealed that discussion as a teaching strategy is one of the best ways of helping students to understand and learn ideas. Hake (1993) further stated in the same study that when students are given the chance to talk about things, it becomes easier to find out their knowledge in that topic. In a similar study by Akpan (1992) it was echoed that in order that learners see clearly how an idea applies to everyday life, they must be given the opportunity to use the discussion approach, and that the teacher only acts as a catalyst during the interaction among them. Graves (1985) in his earlier studies stated that in situations where class discussions are frequent, each student develops self confidence since he realizes that he is contributing something. This method according to Graves (1985) provides an excellent opportunity for students to practice their oral communication skills. It also encourages critical and evaluative thinking (Graves, 1985). Again the activities done by the private school students enable them to learn by doing. In another study by Mensah (1992), he found out that activity method of teaching science assists learners to discover their own knowledge. According to Mensah (1992), activity method also leads to the acquisition of process skills such as measuring, recording, analyzing and interpretation of data which the learners may need in the course of their schooling and working in future.

It appears students in the private schools are taught using more of the acceptable methodologies in teaching, especially in integrated science than their counterparts in the public schools. It is therefore very easy to conclude that students in the private schools are likely to understand and perform better at tasks.

\section{I: Does your science teacher use teaching and learning materials (TLMs) during science lessons?}

A1: Our science teacher uses TLMs once in a while but not always. We wish he uses the TLMs anytime he teaches science. This is because there are certain topics which are very difficult to understand but with the help of the TLMs, one can easily understand.

A2: I remember the last time our science teacher used TLMs was when some officers from the education office came to see his teaching. Apart from that he has not used them.

B1: Our science teacher uses a lot of TLMs anytime we have science lessons. This makes the science lessons more practical and real to us.

B2: Almost every topic that our science teaches us, he uses a TLM. The lesson therefore becomes very interesting.

Students from public school were asked if their science teachers use TLMs during integrated science lessons. One of the students' response was that the teacher does not use TLMs always and the other's response was that the teacher has used TLMs only once. Their counterparts from the private school said that their teachers use TLMs any time the teachers are teaching them science. It has been indicated in a study by Walklin (1982) that science is a discipline which is understood better through the use of teaching and learning materials. In the same study, it was therefore concluded that materials and equipment play a very important role in the teaching and learning of science. UNESCO (2004) was also concluded that the science teacher needs enough teaching and learning materials in order to help learners to develop scientific skills, knowledge and attitude toward science.

I: Is your school having a library? If yes or no, does it have any effect(s) on your study of science?

A1: Our school has no library facility. Because there is no such facility, it becomes very difficult to have access to books, especially science books, which are very expensive for our parents to buy. We therefore depend on the classroom notes alone.

A2: We have no school library, therefore when we need a reading or text book, our parents have to buy them.

B1: Our school has a library with a lot of story books as well as science books. We also have library time on our school's time table. This helps us to get a lot of books to read especially science books. 
B2: We have a well stocked school library built by some foreign donors with assistance from our old students. We have a lot of science text books that are available to all the students.

None of the two students interviewed from public school had a school library. Meanwhile, their two counterparts from private school said that their respective schools have library facilities. However, studies by Holly and Michele (1994) stated that science library provides suitable opportunity for the student to search for facts in creative and productive way to arrive at their own independent conclusions on a subject. In the same study, Holly and Michele found out that conducive science library facilities enable students to grow in enriched knowledge, ability, skills and interest. It has been pointed out that well furnished libraries with good lighting system promote learning ([NREL], 1991).

I: Do you have adequate classrooms in your school? If yes or no, how does it influence your study of integrated science?

A1: Yes, we have so many classrooms in our school. Some are even not been used. As you are aware, Science is a difficult subject; therefore you need a quiet place to study it. Since we have so many classrooms, one can go into any of them to have your quiet studies.

A2: We have so many classrooms including workshops that are used for pre-vocational skills. Therefore, if someone wants to have his or her personal studies, the person can easily get a place for that.

B1: We don't have so many classrooms and this makes us feel uncomfortable. Therefore there is no place for private or individual studies.

B2: We have few classrooms and as a result of that, group work in science is always done under constraint.

Although, students from public school selected for this study confirmed the availability of adequate classrooms, as whether those classrooms are effectively used during science lessons is another issue. However, it has been indicated in a study elsewhere that spacious and well furnished classrooms with good lighting system promote learning ([NREL], 1991).

\section{Interview items and responses from head teachers}

I: Does supervision see to the success of an educational programme?

A1: Of course, I do agree that supervision sees to the success of any educational programme. When someone is doing something and he/she is regularly supervised, there is the tendency of the task becoming successful

A2: I do believe that in any educational programme, if it is well supervised, there is the likelihood that the said programme will surely succeed.

B1: Yes, of course. A task well supervised, leads to fruition.

B2: When for example, a teacher who is teaching is regularly supervised; he or she is likely to perform very well.

I: Do you often carry out supervision at the basic school during integrated science lessons?

A1: I don't normally supervise science lessons because science is something that I didn't understand right from the secondary school. Even if the teacher teaches the right concept or not, I may not know it. On the other side of the coin, I do supervise the other subjects.

A2: I don't actually supervise science lessons because I believe that the science teacher is capable of doing the right thing with little or no supervision.

B1: Yes, I do supervise, because it is part of my duty as the head of the school. If I do supervise during other subjects such as maths, social studies, etc. what prevents me from doing likewise for integrated science?

B2: I always supervise all lessons including integrated science. This is because my duty is to supervise all teachers under my control.

I: If you are giving the chance to advise your colleague head teachers, will you encourage your fellow head teachers to supervise science teachers during science lessons?

A1: If only the supervisors are comfortable with the subject, then they can do the supervision but if not, I don't think it will be necessary since the science teachers themselves know what is good or not.

A2: If you are a head of an institution, I don't think you should wait till someone tells you to supervise before you do so. 
B1: Yes, I will encourage all head teachers to supervise so as to ensure all teachers irrespective of the subject one teaches, do the right thing at the right time.

B2: Why not? If I'm given the chance, I will encourage my entire colleague head teachers to let supervision be their watch word. This is because, supervision ensures smooth running of educational programmes.

On supervision, all the head teachers from both public and private schools agreed that supervision really sees to the success of all educational programmes. Studies have shown that supervision improves teaching and learning. For example, Pollard (1994) considered supervision as any service for teachers that eventually results in improving instruction, learning and curriculum. In another study by Neagly and Evans (1980), supervision is seen as dynamic, democratic actions designed to improve instructions through the continued growth of all concerned individuals- the child, the teacher, the supervisor, the administrator and the parent or other lay person. In has been echoed in a similar study by Fiore (2001) that instructional supervision is a behaviour officially designated by an organisation that directly affects teacher's behaviour in such a way as to facilitate student's learning and achieve the goals of the organisation.

Considering the supervisory roles played by the head teachers from both private and public schools, it appears head teachers in the private schools do supervise, especially in integrated science than their counterparts in the public schools. It is therefore easy to conclude that teaching will effectively be done in the private schools than in the public schools and also students in the private schools are likely to understand and perform better at tasks.

\section{Conclusions}

The purpose of the study is to find out the opinions of head teachers and students on classroom factors that affect performance of students in integrated science at the Junior High Schools in Kumasi Metropolis. It can be concluded from the results of the study that:

- Most of the students in the private schools perform laboratory work as against their counterparts in the public schools.

- Most of the students in the public schools have greater access to integrated science text books as against their private school counterparts.

- Supervision is regularly carried out in the private schools by the head teachers but not much can be seen at the public schools so this has the tendency of improving teaching and learning of science at the private school.

\section{Recommendations}

- Students from the public schools must be taken through laboratory work by their teachers in order to improve their performance in science.

- Effective supervision must be performed regularly by heads of schools during integrated science lessons. The heads of the public JHS especially, those in the Kumasi metropolis must be made to regularly ensure that their science teachers teach very well during integrated science lessons.

\section{References}

[1] Akpan, O. E. (1992). Towards Creative Science Teaching and Learning in West African Schools. Cape Coast: Catholic Mission Press.

[2] Allen, M. (2008). Now this is what should have happened...: a clash of classroom epistemologies? Eurasia Journal of Mathematics, Science and Technology Education, 4, 319-326.

[3] Balogun, D. A., Okon, S. E., Musaayi, J. C. S., \& Thakur, A. S. (1984). Principles and Practice of Education. London: Macmillan Publishers.

[4] Barmby, P., Kind, P.M., \& Jones, K. (2008). Examining changing attitudes in secondary school science. International Journal of Science Education, 30(8), 1075-1093.

[5] Brown, R. N., Oke, F. E., \& Brown, D.P. (1982). Curriculum and Instruction: An Introduction to Methods of Teaching. London: Macmillan Publishers Ltd.

[6] Corman, A. (2001). Personality Patters of Teaching. New York: Basic Books. 
[7] Driver, R., Guesne, F., \& Tiberghien, A. (1985). Children's Ideas in Science. Milton Keynes: Open University Press.

[8] European Industrial Research Management Association - EIRMA (2009). Attracting young people into science and Technology. Retrieved July 11, 2011, from http://www.eirma.org/eiq/017/pages/eiq2009-017-0015.html on 2011/07/1.

[9] Fiore, D. J. (2001). Creating connections for better schools: How leaders enhance school culture. Larchmont, NY: Eye on Education.

[10] Gordon, S. P. (2005). Standards for instructional supervision: Enhancing Teaching and learning. Larchmont, NY: Eye on Education

[11] Graves. S. (1985). Techniques of attitude scale construction, New York: Appleton-Century Crofts.

[12] Hake, M. I. (1993). The Scientific Study of Personality, London; Routeledge \& Kegan Paul.

[13] Holly, L. S., \& Michele, G. (1994). Creating Laboratory Access for Science . Retrieved July 26, 2009 from www.wright.edu/boilogy/class/main.shtml.

[14] Jenkins, E. W. (1998). The schooling of laboratory work. In Wellington, J. J. (Ed.). Practical work in school science. Pp 112 - 119. London: Routledge.

[15] Kang, N., \& Wallace, C. S. (2005). Secondary science teachers ${ }^{\text {ee }}$ use of laboratory activities: Linking epistemological beliefs, goals, and practices. Science Education, 89, 140-165.

[16] Kimball, W., \& Lovell, J.T. (1983). Supervision for Better Schools, (5 ${ }^{\text {th }}$ Ed). Englewood Cliffs: Prentice Hall

[17] Mensah, S. K.E. (1992). Source Book for Science Tutor and Professional. Cape Coast: Catholic Mission Press.

[18] National Research Council (NRC) (1999). Transforming Undergraduate Education in Science, Mathematics, Engineering, and Technology. Washington, DC: National Academies Press.

[19] Neagley, R. L., \& Evans, N. D. (1980). Handbook for Effective Supervision of Instruction, $\left(3^{\mathrm{rd}}\right.$ Ed). Englewood Cliffs, N.J: Prentice-Hall.

[20] Northwest Regional Education Laboratory (NREL). (1991). Effective schooling practices: A research synthesis. Portland, OR: Author.

[21] Onwu, G.O.M., \& Stoffels, N. (2005). Instructional functions in large, under resourced science classes: Perspectives of South African teachers.Perspectives in Education, 23(3), 79 - 91.

[22] Owusu, M. (2011). Classroom factors that affect the performance of students in integrated science. Unpuublished Mphil Thesis, University of Education, Winneba, Ghana.

[23] Perrot, E. (1982). Adolescent character and personality. New York: Willey.

[24] Pollard, A. (1994). Society and education, Boston: Allyn and Bacon.

[25] Reisman, T., \& Payne, A. (1987). Social climate in high schools. Washington, D.C.: Reis. Monog.

[26] Smith, L. (1990). Manual descriptive of the aptitude test for elementary school teachers-in-training, Toronto: Ont. Dent.

[27] UNESCO (2004). UNESCO handbook on science resource materials. London: UNESCO.

[28] Wadsworth, J. B. (1989). Piaget's Theory of Cognitive and Effective Development. (4 ${ }^{\text {th }}$ Ed). New York: Pitman Publishing Inc.

[29] Walklin, L. (1982). Instructional techniques and practice. London: Leckhampton Stanley Thorns Publishers.

[30] Zimmerman, S. (1998). The art of teaching. New York: Knoft. 